\title{
Floral ontogeny of Cneorum tricoccon L. (Rutaceae)
}

\author{
P. Caris ${ }^{1}$, E. Smets ${ }^{1}$, K. De Coster ${ }^{1}$, and L. P. Ronse De Craene ${ }^{2}$ \\ ${ }^{1}$ Laboratory of Plant Systematics, Institute of Botany and Microbiology, K.U.Leuven, Leuven, Belgium \\ ${ }^{2}$ Royal Botanic Garden Edinburgh, Edinburgh, Scotland, UK
}

Received June 1, 2005; accepted August 25, 2005

Published online: January 17, 2006

(C) Springer-Verlag 2006

\begin{abstract}
The floral ontogeny of the Spurge olive (Cneorum tricoccon L.) is studied by means of scanning electron microscopic observations. Special attention is paid to the sequence of initiation of the floral parts, the occurrence of septal cavities, and the development of the nectariferous tissue. The nectary disc arises as a receptacular outgrowth below the ovary and independently from stamen development. By the extensive growth of this voluminous androgynophore, stamen filaments become enclosed by nectary tissue and as a result, they are seated in pits between the lobes of the disc. Between ovary and style, three lobes are present, which are covered with stomata - their function is unknown. The significance of the unusual trimery of the flower is discussed. Floral developmental evidence supports a Rutalean affinity, although more ontogenetic investigations are needed in Rutaceae, subfamily Spathelioideae.
\end{abstract}

Key words: Androgynophore, Cneoraceae, Cneorum tricoccon L., Floral ontogeny, Nectary, Rutaceae, Spurge olive.

Cneorum L. is a small genus of evergreen shrubs, with a restricted distribution. Traditionally, it has been placed in a family of its own, namely Cneoraceae. Cneorum tricoccon $\mathrm{L}$. is found within the maquis of the western Mediterranean region. C. trimerum (Urb.)
Chod. is known from Cuba, but was treated as a synonym of $C$. tricoccon by LobreauCallen and Jérémie (1986). A third species C. pulverulentum Vent. is endemic to the Canary Islands. It is sometimes treated as a separate genus Neochamaelea (Engl.) Erdtm., mainly on the basis of palynological data, presence of a specific kind of hairs, multiflowered inflorescences, presence of tetramerous flowers instead of trimerous flowers, and a different phytochemistry (Erdtman 1952, Straka et al. 1976, Lobreau-Callen et al. 1978, Mabberley 1997). However, Neochamaelea is strongly similar to Cneorum in its seed structure (Boesewinkel 1984). The family Cneoraceae has traditionally been placed in Sapindales (e.g. Cronquist 1981) or Rutales (e.g. Straka et al. 1976, Lobreau-Callen et al. 1978, Thorne 1992, Takhtajan 1997). Typical characters of these orders are a woody habit, estipulate leaves, and hypogynous flowers with one or two ovules per carpel and a nectary disc. Possible relatives of Cneoraceae are the Meliaceae, Rutaceae, Simaroubaceae, and Zygophyllaceae (Lobreau-Callen et al. 1978, Cronquist 1981, Boesewinkel 1984, Chase et al. 1999).

Present phylogenetic systems treat Cneorum as a member of Rutaceae. In a cladistic 
analysis by Chase et al. (1999) based on molecular data of the chloroplast genes $r b c \mathrm{~L}$ and $\operatorname{atp} \mathrm{B}$, Rutaceae appear to be paraphyletic. The genera Cneorum (or Neochamaelea because they used $C$. pulverulentum; Cneoraceae), Harrisonia R.Br. ex A.Juss. (Simaroubaceae), and Ptaeroxylon Eckl. \& Zeyh. (Ptaeroxylaceae) form the sister group of a clade consisting of Dictyolomatoideae and Spathelioideae, two monogeneric subfamilies of Rutaceae, as defined by Engler (1931). Therefore, they defined Rutaceae in a broad sense, including Cneorum, Harrisonia, Ptaeroxylon, Dictyoloma A.Juss., and Spathelia L. in a re-circumscribed subfamily Spathelioideae. They point to the necessity of additional morphological and anatomical data to support their hypotheses.

The results of Chase et al. (1999) are confirmed by the angiosperm phylogeny group (APG 2003): Meliaceae, Rutaceae (including Cneoraceae and Ptaeroxylaceae), and Simaroubaceae are included in the Sapindales (eurosids 2), whereas Zygophyllaceae belong to the eurosids 1 .

The flower of Cneorum is unusual in two respects: flowers are trimerous and the ovary has septal cavities that are reminiscent of septal nectaries and are highly similar to the slits occurring in Koelreuteria Laxm. (see Baum 1950, Daumann 1974). The occurrence and significance of the septal cavities has been discussed on a number of occasions by Schmid (1985), Ronse De Craene et al. (2000), and Smets et al. (2000), who conclude that these cavities are not nectariferous, but are a deepreaching extension of the stigma. This has to be confirmed for Cneorum.

In this paper, we present the results of a floral ontogenetical study of C. tricoccon, with special emphasis on the development of the nectary and the androgynophore.

\section{Materials and methods}

We studied flowers and floral buds of Cneorum tricoccon L. (specimen $n^{\circ} 1975-1942$; vouchers $n^{\circ} \mathrm{S}$ 2679 (BR) and $\mathrm{n}^{\circ} \mathrm{S} 3051$ (BR)). The material was collected in the greenhouses of the National Botanic Garden of Belgium in Meise and preserved in FAA. The buds were dissected for SEM observation in $70 \%$ ethanol under a Wild M3 stereomicroscope (Leica Microsystems AG, Wetzlar, Germany), equipped with a cold light source (Schott KL 1500; Schott-Fostec LLC, Auburn, New York, USA). They were washed twice for five minutes with $70 \%$ ethanol before being exposed to a mixture $(1: 1)$ of $70 \%$ ethanol and DMM (dimethoxymethane) for a further five minutes. Next, the material was placed in pure DMM for 20 minutes, and critical point dried using liquid $\mathrm{CO}_{2}$ in a Bal-Tec CPD 030 critical point dryer (BAL-TEC AG, Balzers, Liechtenstein). The material was mounted onto stubs using Leit-C and gold-coated in a sputter coater (SPI Supplies, West Chester, Pennsylvania, USA). Observations were made under a JEOL JSM5800LV scanning electron microscope (JEOL Ltd., Tokyo, Japan) at the National Botanic Garden of Belgium.

\section{Results}

The polysymmetric flowers of $C$. tricoccon are trimerous, or occasionally tetramerous (Traveset 1995, own observations); sometimes only two stamens and carpels are present (Traveset 1995). The species is andromonoecious, having both hermaphrodite and staminate flowers. In the latter, the gynoecium is reduced, but both types of flowers appear to produce nectar. The floral sex ratio seems to vary greatly and appears to be mainly depending on environmental factors (Traveset 1995). The flowers develop solitary in the axils of the leaves or they are grouped in small, few-flowered axillary cymes, sometimes adnate to the petiole (Straka et al. 1976, Cronquist 1981). The tetracyclic, trimerous flowers develop in the axils of the leaves (bracts), particularly at the upper part of the branches, and are enclosed by long hairs. On the floral primordium three sepals develop in a rapid sequence (Fig. 1A). The first sepal initiates next to the enclosing leaf and is followed by two other sepals with a variable position. Next, three petal primordia appear 


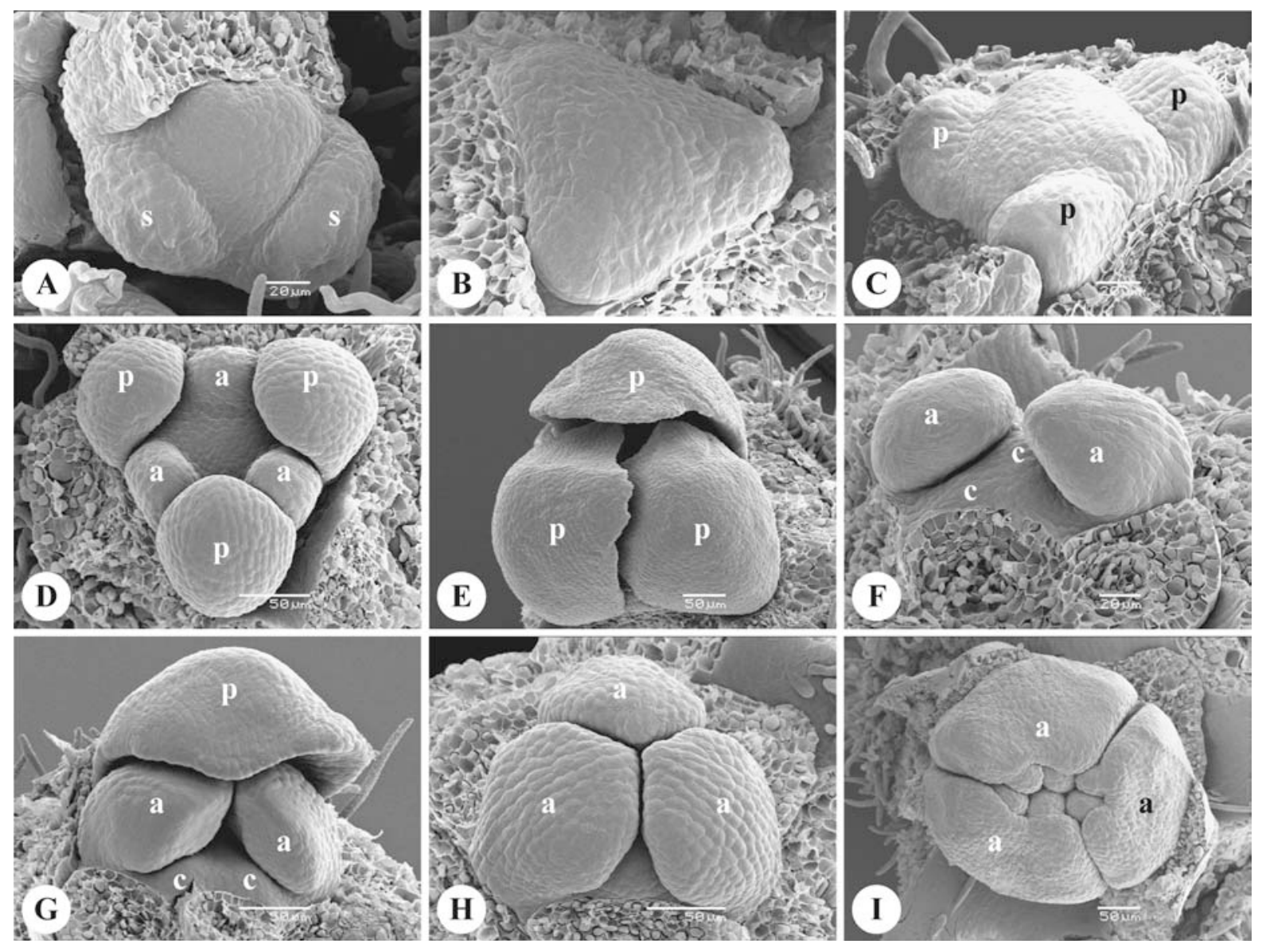

Fig. 1. Early stages of floral development in Cneorum tricoccon. A Inception of the second and third sepal; the first sepal has been removed. B Floral apex, before petal inception; the calyx has been removed. C Simultaneous initiation of three petal primordia $(p)$. D Development of stamen primordia $(a)$, alternating with the petals. E Petals grow fast and hide the underlying stamens from view. F, G Stamen primordia extend in size and become flattened; at the centre of the developing flower, three carpel primordia $(c)$ arise. $\mathbf{H}$ The differentiating stamens are flattened and converge at the centre. I View from above on the differentiated anthers

on the periphery of the triangular floral apex, alternating with the sepals (Fig. 1B, C). Their initiation is also sequential - starting with the two petals adjacent to the first formed sepal to more or less simultaneous (Fig. 1C). The sequence of initiation is reflected in the imbricate aestivation of the petals, where the last formed petal is enclosed by the other two (Fig. 1E). Shortly afterwards, stamen primordia arise in a rapid sequence in antesepalous position (Fig. 1D); the two adaxial stamens are slightly advanced to the abaxial stamen, and this difference in size persists for some time (Fig. 1D, H, I). The distinct sepals and petals enlarge very fast and cover the stamen primordia nearly completely at carpel initiation (Fig. 1E). Three carpel primordia are simultaneously initiated at the centre of the floral apex (Fig. 1F, G) in alternation with the stamen primordia; almost immediately after their initiation the carpels become united at the base (Fig. 1G). Two locules are positioned in an abaxial position and one locule is placed adaxially. Stamen primordia grow into dorsiventral structure compressed against the floral apex (Fig. 1F). The stamen apices join centrally occupying all central available space 
and cover up the carpel primordia (Fig. 1H). Anthers differentiate as broad dithecal pollen producing organs with the adaxial pollen sacs lying closely together above the centre of the flower; a short filament develops below the basifixed anthers (Fig. 1I; 2A). The carpel primordia appear fused only at the base, and as the individual carpel lobes grow up, the basal part also extends in size (Fig. 2A, B). The lower part of the gynoecium differentiates as a three-lobed globular ovary, while the carpel tips differentiate to form the style and three stigmatic lobes (Fig. 2C, D; 3A, B). The swollen style remains short at early stages of development and the stigmatic lobes are covered with papillae (Fig. 3A). Inside the ovary, three septal cavities occur (Fig. 3F, H; 4I) ending into slits at the base of the style. These slits connect to furrows running up the style to the base of the stigmatic lobes (Fig. 3C). The presence of those furrows gives the style a tripartite
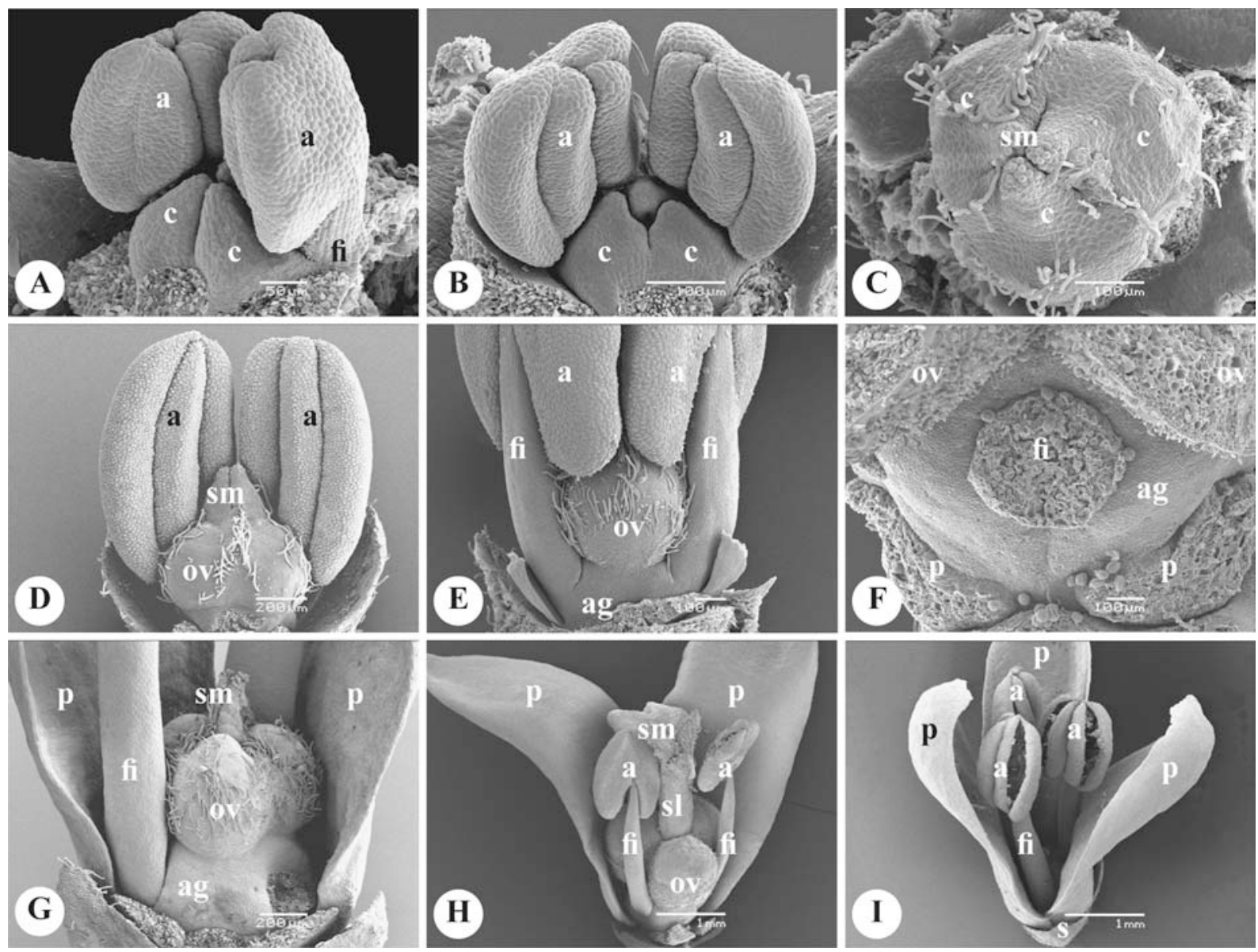

Fig. 2. Later stages of floral development in Cneorum tricoccon. A Hidden by the stamens $(a)$, the carpel primordia $(c)$ develop $(f i=$ filament). B Carpels fuse postgenitally at the base and grow out to form the ovary; the carpel tips remain free and will develop into stigmas afterwards. C Apical view of the gynoecium with developing stigmas (sm). D The ovary (ov) expands and different types of hairs develop on its flanks. E Lateral partial view of base of gynoecium and stamens showing the androgynophore $(a g)$. F Lateral view of the androgynophore with insertion zone of filament; petals $(p)$ removed. G Lateral view of the androgynophore in developing flower; one petal and one stamen removed. H The style $(s l)$ develops at a very late stage, lifting the stigmas above the anthers. I Male flower with reduced ovary $(s=$ sepal) 

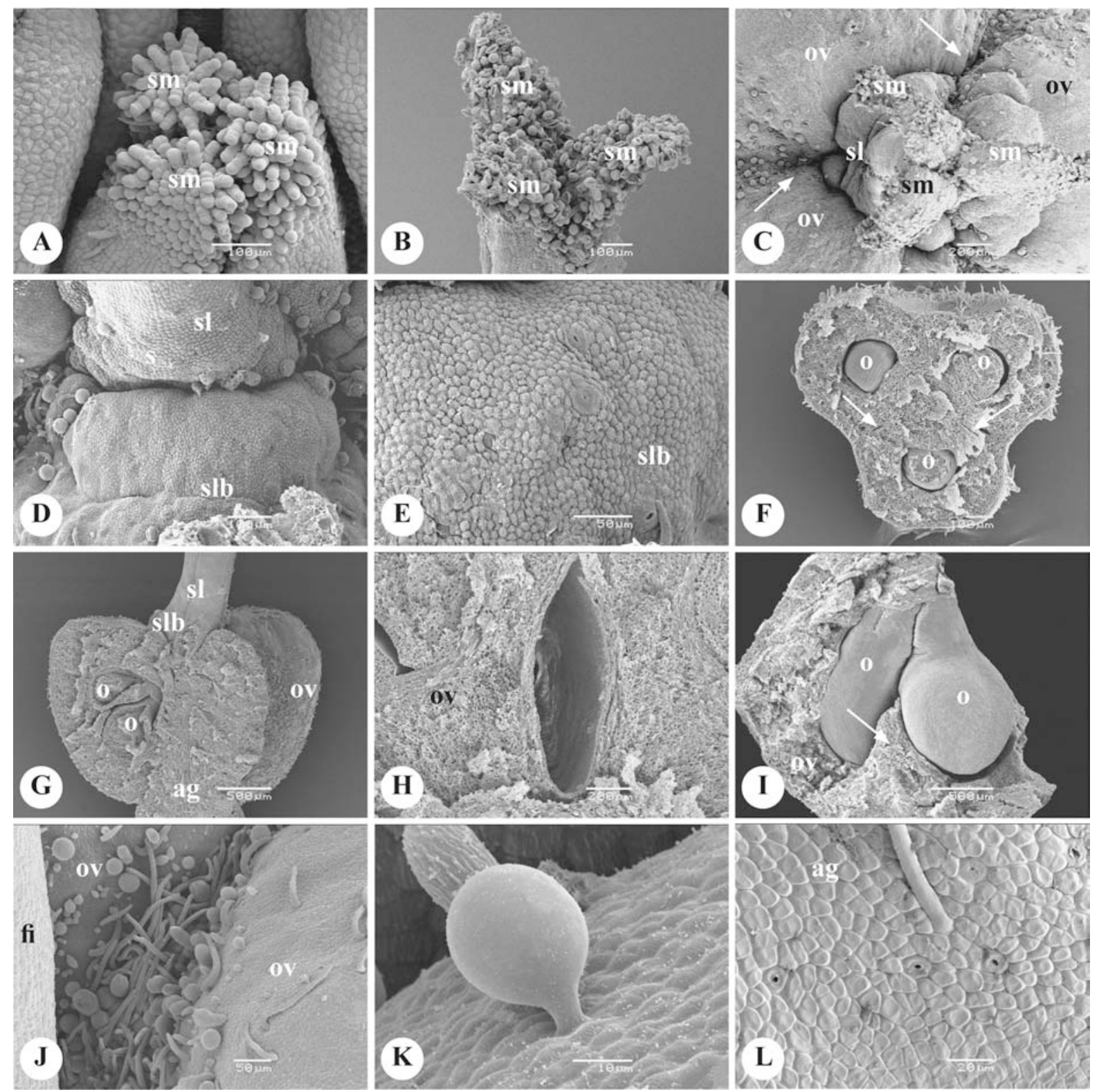

Fig. 3. Gynoecium morphology and development in Cneorum tricoccon. A Detail of the surface of the developing stigmas $(s m)$. B Lateral view of mature stigmatic lobes covered with pollen. C Apical view of mature ovary (ov) showing the inflated style ( $s l$ ), septal slits (arrows), and stigmatic lobes. D Base of the style showing inflated stylar lobe $(s l b)$ covered with stomata. E Detail of this structure at the base of the style with open stomata. F Apical view of transversally sectioned ovary, showing the upper ovule $(o)$ in each locule; arrows point to the septal cavities. G Lateral view of longitudinally sectioned ovary on the androgynophore $(\mathrm{ag})$, showing the superposed attachment of two ovules. H Detail of a septal cavity. I Abaxial view of nearly mature locule showing two parallelly placed ovules with apical insertion and the developing false septum (arrow). $\mathbf{J}$ Detail of curved hairs and club-shaped trichomes lining septal slits in figure $3 \mathrm{C}(f i=$ filament). $\mathbf{K}$ Detail of a club-shaped trichome on the ovary wall. L Detail of nectarostomata on the surface of the nectariferous androgynophore 
appearance (Fig. 3C). At maturity, three swollen lobes of tissue differentiate in between the bulging locules and the stylar base (Fig. 3D). They are covered with stomata resembling nectarostomata (Fig. 3E). Longitudinal sections through the ovary show that the regions at the base of the style stain slightly darker (Fig. 4A, E, F; arrowed), which may possibly indicate secretory activity. Nevertheless, on transverse sections through the top of the ovary, in the zone just below the style, no secretory tissue can be observed (Fig. 4 J, K, L). On the outer ovary surface, two kinds of unicellular hairs develop: long hairs are located all over the surface (Fig. 2C-E, G), while short clubshaped hairs are found essentially near the slits and the swollen emergences at the base of the style (Fig. 3C, D, J, K). Within each locule two pendulous, bitegmic ovules develop on axile placentas (Fig. 4A, G, H). The attachment of the two ovules is slightly uneven with one ovule inserted somewhat higher than the other one (Fig. 3G; 4H); ovules are situated next to each other and occupy all space within the locule (Fig. 3I; 4G). During later stages of gynoecium development a partition develops from each carpellary midrib, dividing the locules in two halves; this partition (false septum) separates the two seeds in the mature mericarps (Fig. 3I). At the base of the ovary and filaments a short androgynophore is initiated (Fig. 2E-G). The androgynophore is swollen and encloses the bases of the outgrowing stamen filaments (Fig. 2F; 4B, C). It appears to be nectariferous (Fig. 4D) and many nectarostomata can be observed on its surface (Fig. 3L). The mature flowers (Fig. 2H) have a short calyx, a well-developed, yellow corolla, dithecal and tetrasporangiate anthers on long filaments, and a voluminous tripartite ovary. Occasionally, male flowers develop, in which the gynoecium is reduced (Fig. 2I). The anthers of the introrse stamens open with two longitudinal slits and release the tricolporate pollen grains. The pollen has a clearly striate exine.

\section{Discussion}

Different species of Hymenoptera are reported to visit C. tricoccon (Daumann 1974, Traveset 1995). Flowers are thus undoubtedly insect-pollinated: they have sticky pollen and they produce nectar as a floral reward. In $C$. tricoccon, the pollen of the male flowers seems to be more fertile (gives a higher fruit set). The number of pollen grains and pollen morphology, however, is similar for both flower morphs. The gynoecium of male flowers is reduced and the stamens appear to be slightly longer than in hermaphrodite flowers (Traveset 1995).

The syncarpous ovary has an axile placentation with normally two parallelly placed ovules in each of the three locules, although their insertion level is different. A false septum separates the two ovules within each locule and is often incomplete. The occurrence of false septa in Cneorum is an interesting feature whose function is unknown (see also Ronse De Craene and Smets 1998). Strictly spoken, these are invaginations of the median carpel surface (Weberling 1989). The development of false septa in Cneorum can be considered as a preliminary condition for higher carpel numbers as found in several Rutaceae (e.g. Citrus L., Aegle Correa).

Occasionally, only one or two locules develop (Traveset 1995), or only a single seed develops within a locule (Straka et al. 1976). The reddish fruit is a schizocarp with three mericarpic drupelets (Cronquist 1981). Inside the ovary, septal cavities are present in Cneorum tricoccon (Fig. $3 \mathrm{H}$ ), which could be interpreted as the result from the incomplete postgenital fusion of the individual carpels. Indeed, the cavities run up the length of the septum and end into slits at the base of the style, in connection with furrows running up the stylar surface. Van Tieghem (1898) observed droplets at the base of the style that he described as nectar and therefore, he considered the septal cavities of $C$. tricoccon to be inner septal nectaries. Schmid (1985) found no septal cavities in $C$. pulverulentum. Daumann 


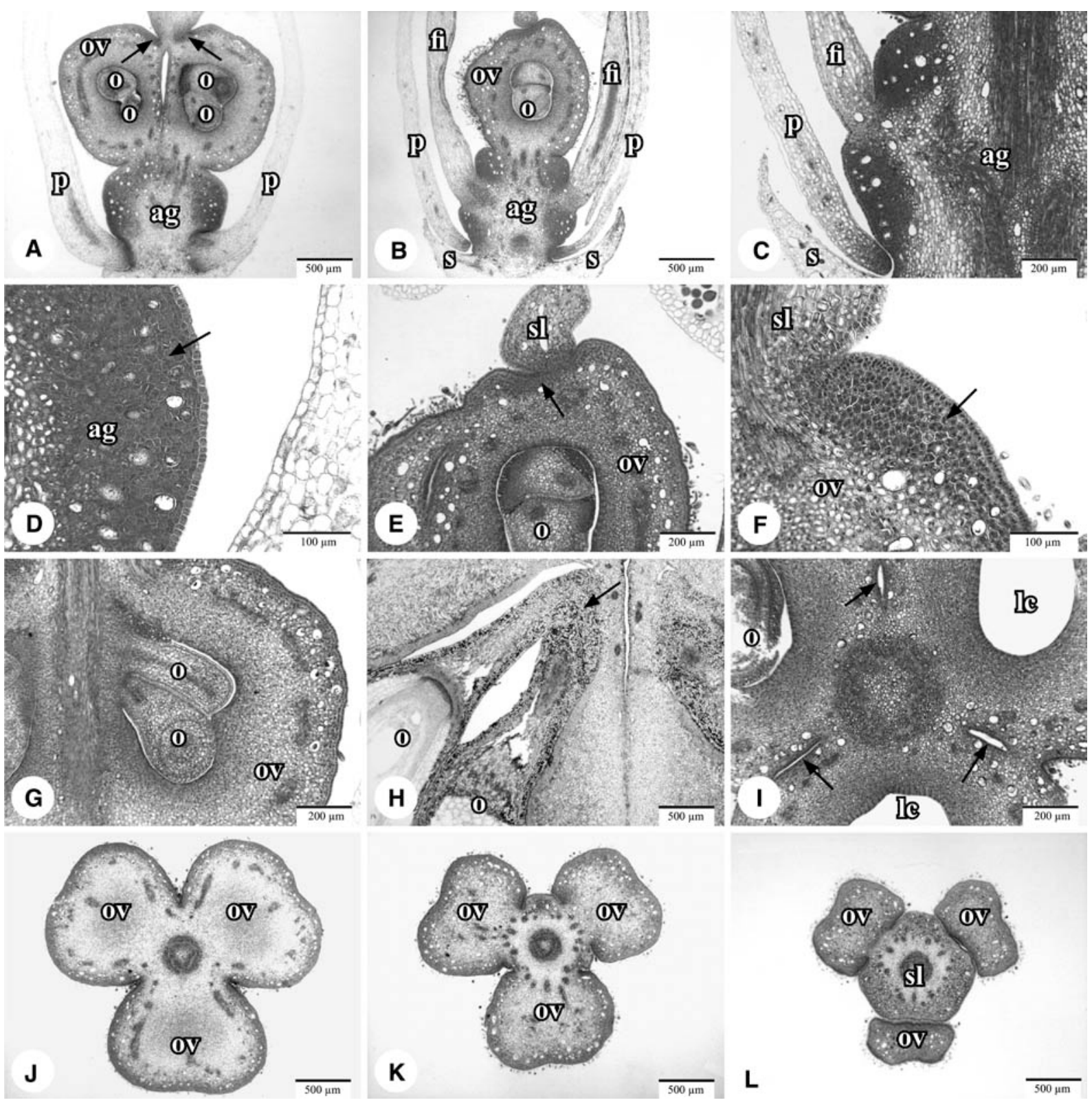

Fig. 4. Anatomy of the gynoecium and the androgynophore in Cneorum tricoccon. A Longitudinal section through two locules of the ovary $(o v)$ with ovules $(o)$ and the nectariferous androgynophore $(a g)$; at the base of the style two intensely stained meristematic regions (arrowed) can be observed ( $p=$ petal). B Longitudinal section through one locule of the ovary and the nectariferous androgynophore ( $f i=$ filament; $s=$ sepal). C Longitudinal section of the nectariferous androgynophore at the point of insertion of the filaments. D Detail of the nectariferous tissue (arrowed) of the androgynophore. E Longitudinal section through a locule near the style $(s l)$ showing a more intensely stained area surrounding the base of the style (arrowed). F Longitudinal section through the region surrounding the base of the style; this region stains a little darker (arrowed), possibly because it consists of young meristematic tissue. G Longitudinal section through the ovary showing two ovules in a locule. H Longitudinal section showing the attachment of the ovules above each other (arrowed). I Transverse section through the top of the trilocular ovary; arrows point to the septal cavities $(l c=$ locule). $\mathbf{J}-\mathbf{L}$ Sequential transverse sections through the upper part of the ovary near the base of the style; no evidence of secretory tissue is found 
(1974) and Schmid (1985) already discussed the occurrence of septal nectaries in angiosperms. They concluded that septal nectaries are exclusive of monocotyledons (see also Smets and Cresens 1988, Van Heel 1988, Smets et al. 2000). Indeed, Daumann (1974) did not find any secretion or nectariferous tissue associated with the septal cavities of C. tricoccon from cultivated plants and wild populations alike. Schmid (1985) confirmed his results and concluded that there is no reason at all to consider the septal cavities of $C$. tricoccon to represent remains of former septal nectaries or a vague inception for future septal nectaries. The cavities may play a role in the schizocarpic nature of the fruit, or be similar to the cavities of Koelreuteria where they apparently play a role in the excretion of stigmatic exudates (Ronse De Craene et al. 2000).

Our observations support the development of a receptacular outgrowth at the centre of the flower that lifts up the gynoecium and the episepalous stamens. The filaments fit in pits in between the carpel lobes. The zone below the stamen insertion remains short and some authors have described a gynophore for Cneoraceae (e.g. Straka et al. 1976). Daumann (1974) described this structure in C. tricoccon as situated in between the perianth on the one hand, and the gynoecium on the other hand. However, the figures (Fig. 4A, B) clearly indicate that instead of a gynophore, we have to do with an androgynophore, which develops at a late stage in the ontogeny, after the differentiation of the gynoecium.

Although septal nectaries are absent from Cneorum, the flowers produce nectar abundantly through nectarostomata that are scattered over the whole surface of the androgynophore. Daumann (1974) and Schmid (1985) called this a disc, but Smets prefers to avoid this term and according to his typology the persistent nectary is axial (Smets 1988). A similar type of nectary was found on the androgynophore of Koelreuteria paniculata Laxm. of Sapindaceae (Ronse De Craene et al. 2000). In Koelreuteria the nectary develops essentially as an extrastaminal structure, while its development is more intrastaminal in Cneorum. It is unknown to us whether the lobes situated between ovary and style are nectariferous. The lobes are covered with open stomata and at first glance they look like nectaries. Moreover, they are situated at the base of the style, close to the slits between the locules, where Van Tieghem (1898) observed nectar droplets. If these lobes are nectaries indeed, than the flower of Cneorum would be highly exceptional in bearing two kinds of nectaries, namely a receptacular one and a gynoecial one. Nevertheless, we did not find convincing evidence of secretory activity at the stylar base. Daumann (1974), who observed pollinators in the field, reports that insects land on the stigma, and collect nectar from the androgynophore. They seem not interested in the basal region of the style (Daumann 1974). So most probably, the androgynophore is the only nectar-secreting structure in the flower. The gynoecial stomata may possibly function as scent producers (osmophores).

According to Daumann (1974), three types of unicellular trichomes are present on the ovary: upright ones, hairs that are curved to a greater or lesser extent, and club-shaped trichomes. This study demonstrates the presence of these trichomes, although a differentiation between straight and curved trichomes seems unnecessary. $\mathrm{T}$ and $\mathrm{Y}$ shaped trichomes occur on the vegetative parts of Neochamaelea (Straka et al. 1976), while Cneorum is glabrous; we did not observe these trichomes in the flowers.

The floral development of Cneorum shows a tendency for unidirectionality by a more pronounced development of one side of the flower, particularly in petals and stamens. Contrary to zygomorphic flowers with a clearly unidirectional development (e.g. Tucker 1984, Endress 1998), the sequence shifts for $180^{\circ}$ between alternating whorls. The occurrence of trimerous flowers is rare in the higher eudicots. The fact that the sister taxon of Cneorum tricoccon is tetramerous supports a derivation from a higher merosity, 
viz. pentamery or tetramery. We did not find any evidence of fusion of primordia during the ontogeny of Cneorum. In Neochamaelea the tetramerous calyx is inserted in a median and transversal position (e.g. Straka et al. 1976). Loss of one sector in the flower of Cneorum may be responsible for the unusual initiation of organs within a whorl. Other species of Rutales and Sapindales are generally pentamerous or tetramerous.

Systematic relationships. Cneorum has a striking combination of characters found in the monocots (trimery, septal cavities, and striate pollen. These similarities are obviously homoplasious and the basic floral diagram differs in the orientation of the carpels (two adaxial and one abaxial in most monocots, contrary to Cneorum; Ronse De Craene et al. 2003). The occurrence of septal cavities, a superior ovary with three locules and six ovules, a capitate style, an androgynophore, and the axial nectary are features regularly occurring in Sapindaceae (Ronse De Craene et al. 2000). On the other hand there are several characters linking Cneorum with Rutaceae, e.g. haplostemony, a similar nectary, rapid petal growth. Unlike the Rutaceae there are no secretory cavities in Cneoraceae. $\mathrm{Y}$ and $\mathrm{T}$ shaped trichomes are absent from Rutaceae, but occur in Meliaceae, Burseraceae, and Zygophyllaceae. Trimerous flower are occasionally found in Meliaceae and Burseraceae. Rutaceae are 2-5merous and have a gynophore and intrastaminal nectary. Boesewinkel (1984) demonstrated that the seed coat of Cneoraceae is closest to Rutaceae, but that it is reduced in the former.

More observations, including floral developmental studies are obviously needed for several taxa of the Rutales, especially of subfamily Spathelioideae, including Harrisonia, Ptaeroxylon, Dictyoloma, and Spathelia.

The authors would like to thank Marcel Verhaegen for technical assistance with the SEM observations and the director of the National Botanic Garden at Meise for permission to collect the floral material of $C$. tricoccon. This research is supported by grants from the Research Council of the K.U.Leuven (OT/01/25) and the Fund for Scientific Research - Flanders (Belgium) (G.0268.04; 1.5.003.05N).

\section{References}

APG (The Angiosperm Phylogeny Group) (2003) An update of the Angiosperm Phylogeny Group classification for the orders and families of flowering plants: APGII. Bot. J. Linn. Soc. 141: 399-436.

Baum H. (1950) Septalspalten im Gynözeum von Koelreuteria paniculata. Österr. Bot. Z. 97: 207215.

Boesewinkel F. D. (1984) Development of ovule and seed coat in Cneorum tricoccon L. (Cneoraceae). Acta Bot. Neerl. 33: 61-70.

Chase M. W., Morton C. M., Kallunki J. A. (1999) Phylogenetic relationships of Rutaceae: a cladistic analysis of the subfamilies using evidence from $r b c \mathrm{~L}$ and $a t p \mathrm{~B}$ sequence variation. Amer. J. Bot. 86: 1191-1199.

Cronquist A. (1981) An integrated system of classification of flowering plants. Columbia University Press, New York.

Daumann E. (1974) Zur Frage nach dem Vorkommen eines Septalnektariums bei Dicotyledonen. Zugleich ein Beitrag zur Blütenmorphologie und Bestäubungsökologie von Buxus L. und Cneorum L. Preslia 46: 97-109.

Endress P. K. (1998) Antirrhinum and Asteridae evolutionary changes of floral symmetry. Symp. Ser. Soc. Exp. Biol. 51: 133-140.

Engler A. (1931) Cneoraceae. In: Engler A., Prantl K. (eds.) Die natürlichen Pflanzenfamilien (sec. ed.) Bd. 19a. W. Engelmann, Leipzig, pp. 184187.

Erdtman G. (1952) Angiosperm pollen morphology and taxonomy. Almqvist and Wiksell, Stockholm.

Heel W. A., van (1988) On the development of some gynoecia with septal nectaries. Blumea 33: 477-504.

Lobreau-Callen D., Jérémie J. (1986) L'espèce Cneorum tricoccon (Cneoraceae, Rutales) représentée à Cuba. Grana 25: 155-158.

Lobreau-Callen D., Nilsson S., Albers F., Straka H. (1978) Les Cneoraceae (Rutales): Étude taxonomique, palynologique, et systématique. Grana 17: 125-139. 
Mabberley D. J. (1997) The plant book - A portable dictionary of the vascular plants (2nd ed.). Cambridge University Press, Cambridge.

Ronse De Craene L. P., Smets E. (1998) Meristic changes in gynoecium morphology, exemplified by floral ontogeny and anatomy. In: Owens S. J., Rudall P. J. (eds.) Reproductive biology. Royal Botanic Gardens, Kew, pp. 85-112.

Ronse De Craene L. P., Smets E., Clinckemaillie D. (2000) Floral ontogeny and anatomy in Koelreuteria with special emphasis on monosymmetry and septal cavities. Pl. Syst. Evol. 223: 91-107.

Ronse De Craene L. P., Soltis P. S., Soltis D. E. (2003) Evolution of floral structures in basal angiosperms. Int. J. Plant Sci. 164 (5 Suppl.): S329-S363.

Schmid R. (1985) Functional interpretation of the morphology and anatomy of septal nectaries. Acta Bot. Neerl. 34: 125-128.

Smets E. (1988) La présence des 'nectaria persistentia' chez les Magnoliophytina (Angiospermes). Candollea 43: 709-716.

Smets E., Cresens E. (1988) Types of floral nectaries and the concepts "character" and "characterstate" - a reconsiderationv. Acta Bot. Neerl. 37: $121-128$.

Smets E., Ronse De Craene L. P., Caris P., Rudall P. J. (2000) Floral nectaries in monocotyledons: distribution and evolution. In: Wilson K. L., Morrison D. A. (eds.) Monocots: systematics and evolution. CSIRO Publishing, Melbourne, pp. 230-240.
Straka H., Albers F., Mondon A. (1976) Die Stellung und Gliederung der Familie Cneoraceae (Rutales). Beitr. Biol. Pfl. 52: 267-310.

Takhtajan A. (1997) Diversity and classification of flowering plants. Columbia University Press, New York.

Thorne R. F. (1992) An updated phylogenetic classification of the flowering plants. Aliso 13: 365-389.

Traveset A. (1995) Reproductive ecology of Cneorum tricoccon L. (Cneoraceae) in the Balearic Islands. Bot. J. Linn. Soc. 117: 221-232.

Tucker S. C. (1984) Unidirectional organ initiation in Leguminous flowers. Amer. J. Bot. 71: 11391148.

Van Tieghem M. Ph. (1898) Sur les Cnéoracées. Bull. Mus. Hist. Nat. (Paris) 4: 241-244.

Weberling F. (1989) Morphology of flowers and inflorescences. Cambridge University Press, Cambridge.

Addresses of the authors: Pieter Caris (correspondence; e-mail: pieter.caris@bio.kuleuven.be), Erik Smets and Katrien De Coster, Laboratory of Plant Systematics, Institute of Botany and Microbiology, K.U.Leuven, Kasteelpark Arenberg 31, 3001 Leuven, Belgium. Louis Ronse De Craene, Royal Botanic Garden Edinburgh, 20A Inverleith Row, Edinburgh EH3 5LR, Scotland, UK. 